\title{
EFFECT OF HEAT STRESS ON PROTEIN REQUIREMENTS FOR MAINTENANCE OF EGYPTIAN NUBIAN GOATS
}

T.M. El-Bedawy ${ }^{1}$, G. Ashour ${ }^{1}$, Faten F. Abou Ammou ${ }^{2}$ and M. H. ElShafie $^{2}$

1- Department of Animal Production, Faculty of Agriculture, Cairo University, Giza, Egypt, 2- Animal Production Research Institute, Ministry of Agriculture, Cairo, Egypt

\section{SUMMARY}

This study was conducted to determine protein requirements for maintenance (RCP)of Egyptian Nubian goats under $25^{\circ} \mathrm{C}$ and $35^{\circ} \mathrm{C}$ environmental temperature. Protein requirements for maintenance of goats were determined under the two environmental temperatures from nitrogen balance data applying statistical, factorial and graphical methods. Goats were fed four rations differed in dietary protein concentrations $(9.38,11.81,13.22$ and $14.74 \%)$.

Results indicated that RCP calculated by any method was lower for goats under $35^{\circ} \mathrm{C}$ than those under $25^{\circ} \mathrm{C}$ by about $25 \%$; averaging $5.63 \mathrm{~g} / \mathrm{Kg} \mathrm{W}^{0.075}$ for goats under $25^{\circ} \mathrm{C}$ and $4.31 \mathrm{~g} / \mathrm{Kg} \mathrm{W}^{0.075}$ for those under $35^{\circ} \mathrm{C}$.

Keywords: goat, protein, maintenance requirement, heat stress

\section{INTRODUCTION}

Protein is the most expensive nutrient in livestock feeding; therefore, it is often a limiting factor of its productivity. (Singh and Sengar, 1970). The maintenance requirement of protein comprises a great amount of daily intake of ruminant rations. The amount of protein needed for maintenance is nearly consisting $40-50 \%$ of the total protein intake (NRC, 1985).

Determination of protein for maintenance is influenced by many factors, i.e. animal (age, species, breed, physiological status and activity), diets (composition, energy-protein ratio, level of degradable protein and essential amino acid content), climatic conditions (ambient temperature and relative humidity) and methodology by which protein requirements are determined (El-Bedawy et al., 1998).

The objective of this study is to determine the effect of environmental temperature on nitrogen metabolism and maintenance requirement of protein for Egyptian Nubian goats applying different experimental procedures.

\section{MATERIALS AND METHODS}

The effect of heat stress on nitrogen metabolism and protein requirements for maintenance of Egyptian Nubian goats was determined through nitrogen metabolism trial (nitrogen balance trials). Eight Egyptian Nubian goat bucks aged $12-18$ months with body weight ranging from 25.5 to $36.0 \mathrm{Kg}$ were used in this trial. The bucks were randomly divided into two groups each of four animals. The first group was

Issued by The Egyptian Society of Animal Production 
maintained under constant $25^{\circ} \mathrm{C}$ and $60 \%$ relative humidity $(\mathrm{RH})$ while, the second group was kept under constant $35^{\circ} \mathrm{C}$ and $60 \% \mathrm{RH}$.

The bucks were fed isocaloric rations but differed in crude protein $(\mathrm{CP})$ content, at the level of $2.2 \% \mathrm{DM}$ of live body weight. The percentage of CP in the experimental rations was 9.83, 11.81, 13.22 and 14.74 for rations 1, 2, 3 and 4, respectively. Ingredient and chemical composition of the experimental rations are presented in Tables ( 1 and 2). The rations were fed individually in metabolic cages for 21 days as preliminary period followed by 7 days for total collection of feces and urine. Initial and final body weights were recorded for each experiment. Drinking water was available in free choice and daily water consumption was recorded. Feeds were offered once a day at 9:30 h. and residues, if any, were daily collected and weighed to determine daily feed intake. Feces and urine were collected, a 10\% sample of the collected feces was sprayed with solution of $10 \%$ sulfuric acid and $10 \%$ formaldehyde, then oven dried at $60{ }^{\circ} \mathrm{C}$ for 24 hours. A composite sample of dry feces for each buck was ground and kept at room temperature for nitrogen determination. Urine was collected in clean stopper plastic bottles each containing $50 \mathrm{ml}$ of $10 \%$ sulfuric acid. Daily $10 \%$ sample of collected urine was used for nitrogen determination.

Chemical composition of feeds, feces and nitrogen contents of the urine were determined according to the standard methods of A.O.A.C. (1984).

Table 1. Ingredient composition of the experimental rations

\begin{tabular}{lccccc}
\hline & \multicolumn{5}{c}{ Dietary CP \% } \\
\cline { 3 - 6 } Ingredient & IFN & $\mathbf{9 . 8 3}$ & $\mathbf{1 1 . 8 1}$ & $\mathbf{1 3 . 2 2}$ & $\mathbf{1 4 . 7 4}$ \\
\cline { 3 - 6 } & & & & & \\
\hline Yellow corn & $4-02-931$ & 42 & 35 & 28 & 21 \\
Barley grain & $4-00-549$ & 21 & 21 & 21 & 21 \\
Soybean meal & $5-04-604$ & 3.5 & 7 & 10.5 & 14 \\
Wheat bran & $4-05-190$ & 1.75 & 5.25 & 8.75 & 12.25 \\
Rice straw & $1-04-077$ & 30 & 30 & 30 & 30 \\
Min. \& vit. Premix & & 1.75 & 1.75 & 1.75 & 1.75 \\
\hline
\end{tabular}

Table 2. Chemical compositions of the experimental rations

\begin{tabular}{lcccc}
\hline & \multicolumn{4}{c}{ Dietary CP \% } \\
\cline { 2 - 5 } Chemical composition & $\mathbf{9 . 8 3}$ & $\mathbf{1 1 . 8 1}$ & $\mathbf{1 3 . 2 2}$ & $\mathbf{1 4 . 7 4}$ \\
\hline Dry matter & 90.90 & 90.90 & 91.11 & 91.18 \\
Chemical composition as DM basis & & & & \\
Organic matter & 92.5 & 93.72 & 92.22 & 92.15 \\
Crude protein & 9.83 & 11.81 & 13.22 & 14.74 \\
Crude fiber & 14.35 & 14.89 & 15.04 & 15.48 \\
Ether extract & 1.71 & 2.02 & 2.10 & 1.86 \\
Nitrogen free extract & 66.47 & 65.00 & 61.96 & 60.07 \\
Ash & 7.50 & 6.28 & 7.87 & 7.85 \\
\hline
\end{tabular}




\section{Quantification of nitrogen requirement for maintenance}

Nitrogen balance was calculated by the difference between nitrogen intake and nitrogen outgo in feces and urine. Nitrogen requirement for maintenance was calculated applying statistical, factorial and graphical methods.

Statistical method based on the relationship between nitrogen intake and nitrogen balance as mentioned by Singh and Mudgal (1991) was used to calculate the nitrogen requirements by regression of nitrogen intake (NI) on nitrogen balance (NB), NI as dependent variable (Y) and nitrogen balance (NB) as independent variable (X) for the 16 observations in each group. The general regression formula is

$\mathrm{Y}=\mathrm{a}+\mathrm{bx}$, then $\mathrm{NI}=\mathrm{a}+\mathrm{b}(\mathrm{NB})$

At $\mathrm{NB}=$ zero (Nitrogen equilibrium), then $\mathrm{N}$ requirement $=$ the intercept value

Factorial method was used to determine the nitrogen requirement for maintenance according to the following formula applied by Harris and Mitchell (1941) as suggested by Sengar (1980) . N requirement $=$ MFN + EUN/ BV X TD

Endogenous urinary nitrogen (EUN) was calculated by regression of urinary nitrogen $(\mathrm{UN})$ on nitrogen intake $(\mathrm{NI})$ by regression formula: $\mathrm{UN}=\mathrm{a}+\mathrm{b}(\mathrm{NI})$ when $\mathrm{NI}=$ Zero then $\mathrm{UN}=\mathrm{EUN}$,

Metabolic fecal nitrogen (MFN) was calculated by regression of fecal nitrogen (FN) on nitrogen intake (NI) by regression formula

$\mathrm{FN}=\mathrm{a}+\mathrm{b}(\mathrm{NI})$ when $\mathrm{NI}=$ Zero then $\mathrm{FN}=\mathrm{MFN}$

Biological value (BV) of protein was calculated according to the following formula (Mitchell, 1924) BV = [NI- (FN-MFN)-(UN-EUN)/ NI- (FN-MFN)] x 100

True digestibility (TD) of dietary protein was calculated according to the following formula (Mitchell, 1924). TD $=[\mathrm{NI}-(\mathrm{FN}-\mathrm{MFN}) / \mathrm{NI}] \times 100$

Graphical method as described by Majumdar (1960) and Sengar (1980) was applied to determine nitrogen requirement for maintenance. Nitrogen balance values $(\mathrm{mg} \mathrm{N} / \mathrm{Kg} \mathrm{W}$ ) where plotted on (Y) axis against daily nitrogen intake (mg N/Kg W) on (X) axis for each individual animal. The high points were joined to the lowest point. Lines joining these points were extended to cut the ordinate at three level of NI. The lowest level (a) shows the minimum $\mathrm{N}$ intake and the highest level (b) represent the maximum $\mathrm{N}$ intake, at nitrogen equilibrium $(\mathrm{NB}=$ zero) the average of these two values ( $a$ and $b$ ) represents the maintenance nitrogen requirement for each individual buck. Values were averaged for $25^{\circ} \mathrm{C}$ and $35^{\circ} \mathrm{C}$ groups represent maintenance nitrogen requirement for goats under $25^{\circ} \mathrm{C}$ and $35^{\circ} \mathrm{C}$

\subsection{Statistical analysis}

Two factors factorial arrangement was used to test the effect of dietary protein and ambient temperature and their interaction using analysis of variance procedure (Proc. ANOVA).Since the interaction between the dietary protein level and environmental temperature was not significant then it was excluded from the model. Duncan's multiple range tests was used to separate mean effects for the dietary protein and ambient temperature and their interaction (SAS, 1999).

The applied model is:

$\mathbf{Y}_{\mathrm{ijk}}=\mu+\mathbf{a}_{\mathrm{i}}+\mathbf{b}_{\mathrm{j}}++\mathbf{e}_{\mathrm{ijk}}$

Where,

$\mathrm{Y}_{\mathrm{ijk}} \quad=\mathrm{is}$ the vector of observation;

$\mu \quad=$ the overall mean;

$\mathrm{a}_{\mathrm{i}} \quad=$ the effect of $\mathrm{i}^{\text {th }}$ protein level $(\mathrm{i}=1,2,3$ and 4$)$; 
$b_{j} \quad=$ the effect of $j^{\text {th }}$ temperature $(j=1$ and 2$)$;

$\mathrm{e}_{\mathrm{ijk}}=$ the vector of random error normally and independently distributed with ( 0 , $\left.I \sigma^{2}\right)$.

\section{RESULTS AND DISCUSSION}

Effect of dietary protein level and environmental temperature on nutrient digestibilities, water balance and nitrogen balance were determined from nitrogen metabolism trials data. Also, nitrogen requirement was calculated from nitrogen balance data applying different method of calculation.

The mean effects of dietary protein level and environmental temperature on nutrient digestibilities are shown in Table (3). Increasing dietary crude protein from $9.83 \%$ to $11.81 \%$ significantly improved the digestibility of DM, CP and CF. However, the digestibility of OM, EE and NFE were not affected. The increase of dietary CP above $11.81 \%$ showed no parallel increase in nutrients digestibility. These results conform with those found by Woods et al. (1958) which indicated that the nutrient digestibilities increased as the level of dietary protein increased from $4 \%$ to $8 \%$ in sheep rations. Similar results were reported by Bunting et al. (1987) that dry matter and nitrogen digestibilities increased by increasing $\mathrm{CP}$ intake from $12 \mathrm{~g}$ to $21 \mathrm{~g}$ N/day.

The present results of non-significant increase in DM, CP and CF digestibilities by increasing dietary crude protein concentration above 11.81 confirmed the findings of Ahmed and Abdellatif (1995) that increasing dietary CP from $12.8 \%$ to $14.7 \%$ was not associated with an increase in nutrient digestibilities by desert sheep.

Increasing environmental temperature from $25^{\circ} \mathrm{C}$ to $35^{\circ} \mathrm{C}$ caused a slight increase in nutrient digestibilities (from 2-3 digestion unites) but, these differences were not statistically significant (Table 3). McDowell et al. (1969) reported higher nutrient digestibilities by Holstein cows under $32.2^{\circ} \mathrm{C}$ than by those under $15.24^{\circ} \mathrm{C}$. Also, Warren et al. (1974) found that the digestibilities of crude protein and fiber fractions were higher under $32^{\circ} \mathrm{C}$ than those under $18^{\circ} \mathrm{C}$ in Holstein steers. Murad et al. (1994) found that feeding high concentrate diets resulted in higher nutrient digestibilities except crude fiber under $35^{\circ} \mathrm{C}$ but not under $18{ }^{\circ} \mathrm{C}$. It was suggested that the influence of ambient temperature on apparent digestibilities of nutrients depends on diet composition

Increasing dietary crude protein concentrations increased nitrogen intake significantly (Table 4). This result is in agreement with the findings of Helal (2002) who found that nitrogen intake increased by increasing dietary crude protein percentage in Baladi goats.

Increasing nitrogen intake from 9.07 to 11.22 and $12.82 \mathrm{~g} / \mathrm{h} /$ day did not result in a significant increase in fecal nitrogen being $3.57,3.65$ and $3.58 \mathrm{~g} / \mathrm{h} /$ day for the three levels of protein respectively. However, fecal nitrogen output of goats on the highest nitrogen protein intake $(14.54 \mathrm{~g} / \mathrm{h} /$ day $)$ was $4.28 \mathrm{~g} / \mathrm{h} /$ day $(\mathrm{p}<0.05)$ higher than the other three groups (Table, 4). Increasing nitrogen intake from 9.07 to $11.22 \mathrm{~g} / \mathrm{h} /$ day $(\mathrm{p}<0.05)$ increased urinary nitrogen loss from 4.11 to $6.35 \mathrm{~g} / \mathrm{h} /$ day, but the increase in nitrogen intake above $11.22 \mathrm{~g} / \mathrm{h} /$ day was not met by a parallel increase in urinary nitrogen loss. Urinary nitrogen was found to be increased by increasing nitrogen intake by goats (Helal, 2002), sheep (El-Bedawy et al., 1998). This result could 
suggest that fecal nitrogen loss is less affected by increasing nitrogen intake. In this connection, Aarts et al. (1992) reported that the concentration of protein in the diet has a greater impact on urinary excretion than fecal nitrogen excretion.

Table 3. Mean effect of dietary protein level and heat stress on nutrient digestibilities \%

\begin{tabular}{|c|c|c|c|c|c|c|c|c|}
\hline \multirow[t]{2}{*}{ Item } & \multicolumn{4}{|c|}{$\begin{array}{c}\text { Dietary protein, } \\
\%\end{array}$} & \multicolumn{3}{|c|}{$\begin{array}{l}\text { Environmental } \\
\text { temperature }\end{array}$} & \multirow[t]{2}{*}{ SEM } \\
\hline & 9.83 & 11.81 & 13.22 & 14.74 & & $25^{\circ} \mathrm{C}$ & $3^{\circ} \mathrm{C}$ & \\
\hline DM & $67.36^{b}$ & $71.02^{\mathrm{a}}$ & $72.53^{\mathrm{a}}$ & $71.28^{\mathrm{a}}$ & 1.11 & 69.53 & 71.57 & 0.79 \\
\hline OM & 73.83 & 77.06 & 77.08 & 75.65 & 1.04 & 74.98 & 76.83 & 0.73 \\
\hline $\mathrm{CP}$ & $60.06^{\mathrm{b}}$ & $67.44^{\mathrm{a}}$ & $71.85^{\mathrm{a}}$ & $70.68^{\mathrm{a}}$ & 1.53 & 66.23 & 68.78 & 1.08 \\
\hline $\mathrm{CF}$ & $53.89^{b}$ & $64.61^{\mathrm{a}}$ & $64.53^{\mathrm{a}}$ & $56.48^{\mathrm{ab}}$ & 3.07 & 58.26 & 61.49 & 2.17 \\
\hline EE & 84.01 & 76.95 & 80.19 & 73.96 & 3.80 & 77.39 & 80.17 & 2.69 \\
\hline NFE & 79.86 & 81.45 & 81.14 & 81.86 & 0.79 & 80.37 & 81.79 & 0.56 \\
\hline
\end{tabular}

Table 4. Mean effects of protein level and environmental temperature on nitrogen metabolism in goats

\begin{tabular}{|c|c|c|c|c|c|c|c|c|}
\hline \multirow[t]{2}{*}{ Items } & \multicolumn{4}{|c|}{ Dietary protein, $\%$} & \multirow[t]{2}{*}{ SE } & \multicolumn{2}{|c|}{$\begin{array}{c}\text { Environmental } \\
\text { temperature }\end{array}$} & \multirow[t]{2}{*}{ SE } \\
\hline & 9.83 & 11.81 & 13.22 & 14.74 & & $25^{\circ} \mathrm{C}$ & $35^{\circ} \mathrm{C}$ & \\
\hline \multicolumn{9}{|l|}{ g/h/day } \\
\hline Input & $9.07^{\mathrm{d}}$ & $11.22^{\mathrm{c}}$ & $12.82^{\mathrm{b}}$ & $14.54^{\mathrm{a}}$ & 0.37 & 11.77 & 12.06 & 0.26 \\
\hline Fecal & $3.57^{\mathrm{b}}$ & $3.65^{\mathrm{b}}$ & $3.58^{\mathrm{b}}$ & $4.28^{\mathrm{a}}$ & 0.20 & 3.88 & 3.66 & 0.14 \\
\hline Urinary & $4.11^{\mathrm{b}}$ & $6.35^{\mathrm{a}}$ & $6.95^{\mathrm{a}}$ & $7.20^{\mathrm{a}}$ & 0.48 & 6.12 & 6.18 & 0.34 \\
\hline Output & $7.68^{\mathrm{b}}$ & $10.00^{\mathrm{a}}$ & $10.53^{\mathrm{a}}$ & $11.48^{\mathrm{a}}$ & 0.51 & 10.00 & 9.84 & 0.36 \\
\hline Balance & $1.39^{b}$ & $1.22^{\mathrm{b}}$ & $2.29^{\mathrm{ab}}$ & $3.06^{\mathrm{a}}$ & 0.50 & 1.77 & 2.22 & 0.35 \\
\hline \multicolumn{9}{|c|}{$\mathrm{mg} / \mathrm{h} / \mathrm{Kg} W^{0.75} / \mathrm{day}$} \\
\hline Input & $731^{\mathrm{d}}$ & $890^{\mathrm{c}}$ & $994^{\mathrm{b}}$ & $1097^{\mathrm{a}}$ & 8 & 927 & 928 & 6 \\
\hline Fecal & $288^{\mathrm{ab}}$ & $290^{\mathrm{ab}}$ & $278^{\mathrm{b}}$ & $3231^{\mathrm{a}}$ & 14 & 306 & 283 & 10 \\
\hline Urinary & $332^{\mathrm{b}}$ & $508^{\mathrm{a}}$ & $538^{\mathrm{a}}$ & $544^{\mathrm{a}}$ & 37 & 483 & 478 & 26 \\
\hline Output & $620^{\mathrm{b}}$ & $798^{\mathrm{a}}$ & $816^{\mathrm{a}}$ & $867^{\mathrm{a}}$ & 37 & 789 & 761 & 26 \\
\hline Balance & $111^{\mathrm{b}}$ & $92^{b}$ & $178^{\mathrm{ab}}$ & $230^{\mathrm{a}}$ & 38 & 138 & 167 & 26 \\
\hline
\end{tabular}

Total nitrogen output $(\mathrm{p}<0.05)$ increased from 7.68 to $10.00 \mathrm{~g} / \mathrm{h} /$ day by increasing nitrogen intake from 9.07 to $11.22 \mathrm{~g} / \mathrm{h} /$ day $($ Table,4). The bucks showed comparable high total nitrogen output, however not statistically different at 11.22, 12.82 and $14.54 \mathrm{~g} / \mathrm{h} /$ day nitrogen intake. Several authors stated that total nitrogen outgo was increased by increasing dietary protein concentration, in goat (Kurar and Singh, 1982; Chandra and Kurar, 1984 and Helal, 2002), in sheep (Reuben, 1992 and ElBedawy et al., 1998). The changes in nitrogen output resulted in no significant differences in nitrogen balance of goats consuming $9.07,11.22$ or $12.82 \mathrm{~g} / \mathrm{h} / \mathrm{day}$ being $1.39,1.22$ and $2.29 \mathrm{~g} / \mathrm{h} /$ day. However, increased dietary nitrogen to 14.54 $\mathrm{g} / \mathrm{h} /$ day $(\mathrm{p}<0.05)$ increased nitrogen balance to $3.06 \mathrm{~g} / \mathrm{h} /$ day. 
Increasing environmental temperature from 25 to $35{ }^{\circ} \mathrm{C}$ did not significantly affect nitrogen intake, fecal nitrogen and urinary nitrogen but increased $(p>0.05)$ nitrogen balance from 1.77 to $2.22 \mathrm{~g} / \mathrm{h} /$ day or from 138 to $167 \mathrm{mg} / \mathrm{Kg} \mathrm{W}^{0.75} / \mathrm{d}$ (Table, 4).Contradicting results were reported for the effect of the environmental temperature on nitrogen balance. Horton and Rodriguez (1997) found that increasing ambient temperature from 15 to $34^{\circ} \mathrm{C}$ did not affect nitrogen balance in Croix sheep, while Dixon et al. (1999) found that increasing ambient temperature from 15 to $40^{\circ} \mathrm{C}$ decreased nitrogen balance in Merino x Border Licester crossbred sheep.

Maintenance nitrogen requirement was determined applying statistical, factorial, and graphical methods,

\section{Statistical method}

Under $25^{\circ} \mathrm{C}$ the regression equation was found to be $\mathrm{NI}(\mathrm{g} / \mathrm{h} / \mathrm{day})=11.03+0.41$ $\mathrm{NB}(\mathrm{g} / \mathrm{h} /$ day $)$. At nitrogen equilibrium $(\mathrm{NB}=0)$, Nitrogen intake will represent nitrogen requirement for maintenance. Thus the nitrogen requirement for goats under $25^{\circ} \mathrm{C}$ was found to be $5.45 \mathrm{~g} \mathrm{CP} / \mathrm{KgW}^{0.75}$ or $3.6 \mathrm{~g} \mathrm{DCP} / \mathrm{KgW}^{0.75}$ based on protein digestibility $=66.33 \%$ and body weight $=29.5 \mathrm{Kg}$ in average.

Under $35^{\circ} \mathrm{C}$ the regression equation was found to be $\mathrm{NI}(\mathrm{g} / \mathrm{h} / \mathrm{d})=9.25+1.26 \mathrm{NB}$ $(\mathrm{g} / \mathrm{h} / \mathrm{d})$ thus the nitrogen requirement for maintenance was found to be $4.48 \mathrm{~g} \mathrm{CP} / \mathrm{Kg}$ $\mathrm{W}^{0.75}$ or $3.1 \mathrm{~g} \mathrm{DCP} / \mathrm{KgW}^{0.75}$ based on protein digestibility $=69.3 \%$ and body weight $=30.31 \mathrm{Kg}$ in average.

\section{Factorial method}

Nitrogen requirement for maintenance was also quantified applying the factorial method using Harris-Mitchell (1941) formula.

\section{Endogenous Urinary nitrogen (EUN)}

For goats under $25^{\circ} \mathrm{C}$, the correlation coefficient between UN and NI was 0.65 , intercept was -187.27 and regression coefficient was 0.72 and regression formula was $\mathrm{UN}\left(\mathrm{mg} / \mathrm{KgW}^{0.75}\right)=-187.27+0.72 \mathrm{NI}\left(\mathrm{mg} / \mathrm{KgW}^{0.75}\right)$ at $\mathrm{NI}=$ Zero

then $\mathrm{EUN}=\mathrm{UN}=187.27\left(\mathrm{mg} / \mathrm{KgW}^{0.75}\right)$. While, for goats under $35^{\circ} \mathrm{C}$, the correlation coefficient between UN and IN was 0.62 , intercept was 71.87 and regression coefficient was 0.44 and regression formula was $\mathrm{UN}\left(\mathrm{mg} / \mathrm{KgW}^{0.75}\right)=71.87+0.44 \mathrm{NI}$ $\left(\mathrm{mg} / \mathrm{KgW}^{0.75}\right)$ at $\mathrm{NI}=$ Zero then $\mathrm{EUN}=\mathrm{UN}=71.87\left(\mathrm{mg} / \mathrm{KgW}^{0.75}\right)$.

\section{Metabolic fecal nitrogen (MFN)}

For goats under $25^{\circ} \mathrm{C}$, the correlation coefficient was 0.22 , intercept was 243.36 and regression coefficient was 0.07 , then regression formula was $\mathrm{FN}\left(\mathrm{mg} / \mathrm{KgW}^{0.75}\right)=$ $243.36+0.07 \mathrm{NI}\left(\mathrm{mg} / \mathrm{KgW}^{0.75}\right)$. At nitrogen intake $=$ zero then $\mathrm{FN}=\mathrm{MFN}=243.36$ $\left(\mathrm{mg} / \mathrm{KgW}^{0.75}\right)$. While, for goats under $35^{\circ} \mathrm{C}$, the correlation coefficient was 0.27 , intercept was 213.31 and regression coefficient was 0.08 then regression formula was $\mathrm{FN}\left(\mathrm{mg} / \mathrm{KgW}^{0.75}\right)=213.31+0.08 \mathrm{NI}\left(\mathrm{mg} / \mathrm{KgW}^{0.75}\right)$. At nitrogen intake = zero the $\mathrm{FN}$ $=\mathrm{MFN}=213.31\left(\mathrm{mg} / \mathrm{KgW}^{0.75}\right)$.

\section{Biological value of protein (BV)}

The biological value of protein quantified using the formula suggested by Mitchell (1924). The biological value of dietary protein by goats under $25^{\circ} \mathrm{C}$ averaged $51.60 \%$ vs. $48.29 \%$ for goats under $35^{\circ} \mathrm{C}$. 


\section{True digestibility of protein}

True digestibility of protein was calculated using the formula suggested by Mitchell (1924).True digestibility of protein for goats under $25^{\circ} \mathrm{C}$ averaged $86.74 \%$ vs. 86.91 for goats under $35^{\circ} \mathrm{C}$.

Nitrogen requirement for maintenance of goats under $25^{\circ} \mathrm{C}$ was calculated to be $5.5 \mathrm{~g} \mathrm{CP} / \mathrm{KgW}^{0.75}$ or $3.6 \mathrm{~g} \mathrm{DCP} / \mathrm{KgW}^{0.75}$ based on $66.33 \%$ protein digestibility and average body weight $=29.5 \mathrm{Kg}$. For goats under $35^{\circ} \mathrm{C}$ nitrogen requirement for maintenance was found to be $4.15 \mathrm{~g} \mathrm{CP} / \mathrm{KgW}^{0.75}$ or $2.87 \mathrm{~g} \mathrm{DCP} / \mathrm{KgW}^{0.75}$ based on $69.35 \%$ protein digestibility and average body weight $=30.31 \mathrm{Kg}$.

\section{Graphical method}

Data of nitrogen balance $(\mathrm{mg} / \mathrm{KgW})$ for goats fed rations containing varying levels of dietary protein under $25^{\circ} \mathrm{C}$ and $35^{\circ} \mathrm{C}$ was plotted in Figure 1 . The cross points (a) and (b) represented the minimum and maximum nitrogen intake, at nitrogen equilibrium $(\mathrm{NB}=0)$. The respective values $(\mathrm{mg} / \mathrm{KgW})$ of $(\mathrm{a})$ and $(\mathrm{b})$ were 357 and 415 for animal (No. 1), 420 and 445 for animal (No. 2), 335 and 435 for animal (No .3), 357 and 500 for animal (No. 4), 125 and 278 for animal (No. 5), 370 and 386 for animal (No. 6), 188 and 260 for animal (No. 7) and 345 and 395 for animal (No.8) for goats under $25^{\circ} \mathrm{C}$ and $35^{\circ} \mathrm{C}$ respectively.

For goats under $25^{\circ} \mathrm{C}$ the overall mean of maintenance requirement was found to be $5.95 \mathrm{~g} \mathrm{CP} / \mathrm{KgW}^{0.75}$ or $3.94 \mathrm{~g} \mathrm{DCP} / \mathrm{KgW}^{0.75}$ based on $66.33 \%$ protein digestibility and average body weight $=29.5 \mathrm{Kg}$.

For goats under $35^{\circ} \mathrm{C}$ the overall mean of maintenance requirement was $4.30 \mathrm{~g}$ $\mathrm{CP} / \mathrm{KgW}^{0.75}$ or $2.98 \mathrm{~g} \mathrm{DCP} / \mathrm{KgW}^{0.75}$ based on $69.35 \%$ protein digestibility and average body weight $=30.31 \mathrm{Kg}$.

The nitrogen balance trials based on feeding rations containing varying levels of protein content indicated the following assessment of nitrogen requirement for Egyptian Nubian goats as determined by the three methods.

For goats under $25^{\circ} \mathrm{C}$ the requirement was found to be $5.63 \mathrm{~g} \mathrm{CP} / \mathrm{KgW}^{0.75}$ or 3.71 $\mathrm{g} \mathrm{DCP} / \mathrm{KgW}^{0.75}$ based on $66.33 \%$ protein digestibility and average body weight $=$ $29.5 \mathrm{Kg}$. For goats under $35^{\circ} \mathrm{C}$ the requirement was $4.31 \mathrm{~g} \mathrm{CP} / \mathrm{CP} / \mathrm{KgW}^{0.75}$ or $2.98 \mathrm{~g}$ $\mathrm{DCP} / \mathrm{CP} / \mathrm{KgW}^{0.75}$ based on $69.35 \%$ protein digestibility and average body weight = $30.31 \mathrm{Kg}$.

Digestible crude protein for maintenance was $2.9 \mathrm{~g} / \mathrm{KgW}^{0.75}$ for Egyptian Baladi goats Helal (2002) and NRC (1981) recommended $4.15 \mathrm{~g} \mathrm{CP} / \mathrm{KgW}^{0.75}$ or $2.82 \mathrm{~g}$ $\mathrm{DCP} / \mathrm{KgW}^{0.75}$ for goats.

The present study showed that the protein requirement for maintenance of Egyptian Nubian goats was higher under $25^{\circ} \mathrm{C}$ ambient temperature than under $35^{\circ} \mathrm{C}$. This result confirms to the statement of Ames and Willms (1977) that protein requirement for lambs is likely to be reduced during heat stress. 

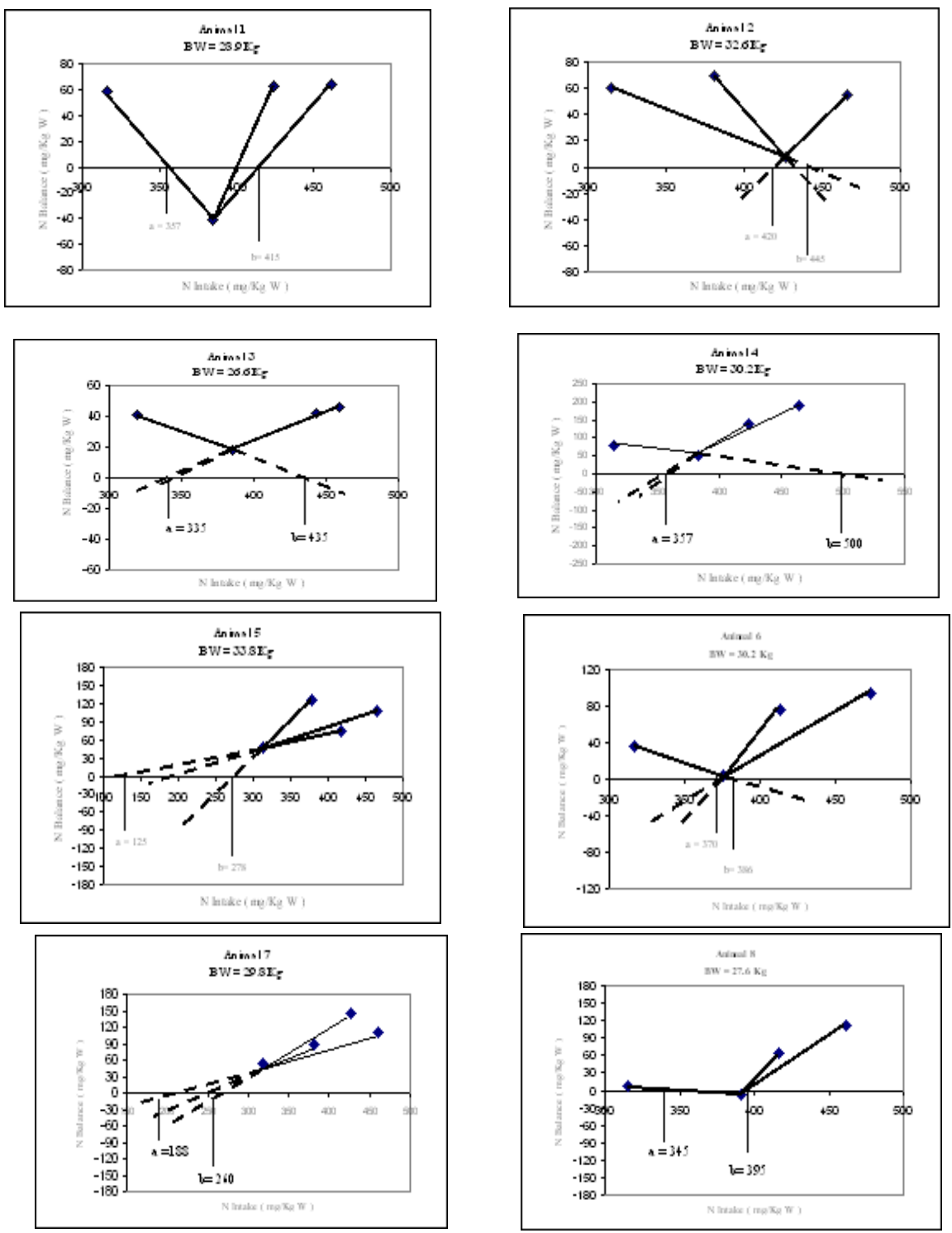

Fig 1. Maintenance nitrogen requirements with graphical method for goats under $25^{\circ} \mathrm{C}$ and $35^{\circ} \mathrm{C}$ 
It is clear that heat stress reduced protein requirement for maintenance by about $25 \%$. This reduction in requirement reflect the reduction in nitrogen out go under heat stress. Animals reduced the amount of feces voided by $11.5 \%$ as well as the concentration of nitrogen in urine by 56.1 and feces by $20 \%$ the reduction could by a part integrated in general reduction in the metabolic heat production in counteraction to the high environmental temperature? Is it triggered by the endocrine - renal mechanism in response to the protein metabolic wastes alongside water balance?

\section{REFERENCES}

A.O.A.C., 1984. Official methods of analysis, $13^{\text {th }}$ Edn., Association of Official Analytical Chimsts., Washington U.S.A. No.2. Ruminants, London

Aarts H. F. M., E. E. Biewinga and H. V. Keulen, 1992. Dairy farming systems based on efficient nutrient management. Neth. J. Agic. Sci. Vol. 40:285

Ahmed, M. M. M. and A.M. Abdellatif, 1995. Effect of dietary protein level on thermoregulation and water economy in desert sheep. Small Rum. Res. Vol. $18: 51$

Ames, D.R. and C.L. Willms, 1977. $69^{\text {th }}$ Annual meeting, Amer. Soc. Anim. Sci. (Abs.):52

Bunting, L.D., J. A. Boling, C.T. Mackown and R.B. Muntifering, 1987. Effect of dietary protein level on nitrogen metabolism in lambs: Studies using ${ }^{15} \mathrm{~N}$ Nitrogen. J. Anim. Sci., 40:714

Chandra, Suresh and C.K. Kurar, 1984. Protein requirements of Beetal goats for maintenance. Indian. J. Anim. Sci., 54:198

Dixon, R. M., Thomas, R. and Holmes, 1999. Interactions between heat stress and nutrition in sheep fed roughage diets. J. Agric. Sci. Camb., 132:351

El-Bedawy, T.M, A.Y El-Badawi and A. A. Abedo, 1998. Protein Requirements for maintenance of Egyptian sheep breeds. Egyptian. J. Anim. Prod. 35 Supp. Issue: 429

Harris, H.E. and H.H. Mitchell, 1941. The value of the urea in the synthesis of protein in the paunch of the ruminant I- In maintenance. J. Nutr. 22:167

Helal, H.G. 2002 Maintenance requirements of energy and protein for maintenance of goats, M.Sc. Thesis, Fac. Agric., Zagazig Univ., Zagazig, Egypt.

Horton, G. M. J. and A. A. Rodiguez, 1997. Comparison between hair (St. Croix) and wool (Targhee and Dorset ) lambs regarding the effect of heat stress on food and water intake, digestive function and nitrogen balance. Archivos latinoamericanos de produccion Animal., 5:79 (Abst.)

Kurar, C. K. and S. P. Singh, 1982. Protein requirement for maintenance of crossbred goats. Indian. J. Dairy Sci., 35:85

Majumdar, B.N., 1960. Studies on goats nutrition. Part II - Digestive protein requirement for maintenance from balance studies. J. Agric. Sci., 54:335.

McDowell, R. E., E.G. Moody, P.G. Van Soest, R.P. Lehmann and G.L. Fred, 1969. Effect of heat stress on energy and water utilization of lactating cows. J. Dairy Sci., 52:188.

Mitchell, H.H., 1924. A method of determination the biological value of protein. J. Biol. Chem., 58:873 
Murad, H.M., T.M. El-Bedawy, M.M. Shafie and S.M. Salem, 1994. Effect of heat stress and dietary roughage level on rumen function, nutrient utilization and water turnover by native Egyptian sheep. Egyptian J. Anim. Prod., 31:361

NRC, 1981. Nutrient Requirement of Domestic Animals. No.15, Nutrient Requirements of Goats, National Research Council, Washington, D.C.

NRC, 1985. Nutrient Requirement of Domestic Animals. NO.6, Nutrient requirements of sheep, National research council, Washington, D.C., USA.

Reuben, N., 1992 Protein requirements of Cameroonian dwarf goats. World Rev. Anim. Prod. 27:23

SAS, 1999. Statistical Analysis System, Users Guide: Statistics. SAS Inc., Gary, N.C.

Sengar, O.P.S., 1980. Indian research on protein and energy requirement for goats. J. Dairy Sci,63:16554

Singh, S.N. and O.P.S. Sengar, 1970. Investigation on milk and meat potentialities of Indian goat Final technical report of PI.840 project No. 47- AH - 8. Dept. A.H. AND dairying, R.B.S. collegee, Bichpuri, Agra, India

Singh, N. and V.D. Mudgal, 1991. Protein requirement of castrated Beetal goat bucks. J. Small Rum. Res. 4:127

Warren, W. P., F. A. Martz, K. H. Asay, E. S. Hilderprand, C. G. Payne, and C.V. Ogt, 1974. Digestibility and rate of passage by steers fed tall fescue Alfalfa and orchard grass hay in 18 and $35^{\circ} \mathrm{C}$ ambient temperature. J. Anim. Sci., 39:93

Woods, W.R., W.D. Gallup and A.D. Tillaman, 1958. Comparative value for sheep of some protein supplements feed at three protein levels. J. Anim. Sci., 17:758 
تأثير الإجهاد الحراري على الإحتياجات الحافظة من البروتين للماعز النويي المصري طه محمد البداوي'، جمال عاشور '، فاتن فهمى أبوعمو'، محمد حسن الثافعي' | - كلية النزاعة جامعة القاهرة- الجبيزة- جم ع، r - معطج بحوث الإنتاج الحيوانس - الدقي - ع م ع أجريت هذه الدراسة بمحطة البحوث الزراعية (معمل فسيولوجى الحيوان), كلية الزراعة جامعة القاهرة

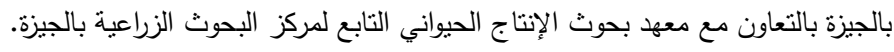

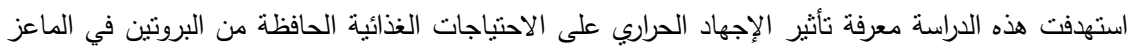

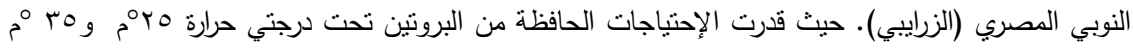

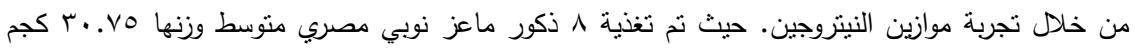

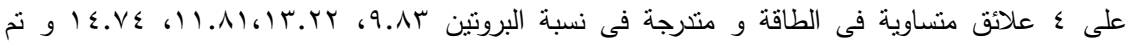

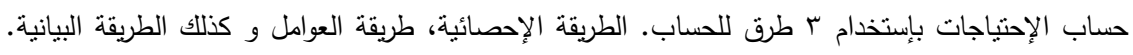

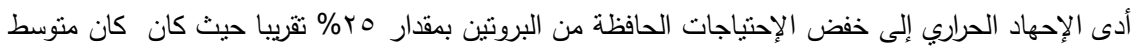

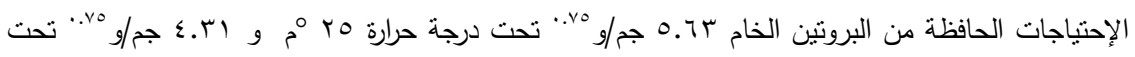

